\title{
EXPLORING THE U.S. STATE E-GOVERNMENT USE OF SOCIAL MEDIA FOR DEMOCRACY
}

\author{
Jensen J. Zhao, Ball State University, jzhao@bsu.Edu \\ Allen D. Truell, Ball State University, atruell@bsu.Edu \\ Melody W. Alexander, Ball State University, malexand@bsu.Edu \\ Sushil Sharma, Ball State University, ssharma@bsu.Edu
}

\begin{abstract}
Social media such as Facebook, Twitter, and YouTube have empowered people to engage in democracy campaigns around the globe. While the totalitarian governments view social media as threats, the democratic governments consider them as opportunities for better engaging people in government affairs. This study explored the U.S. state e-government use of social media. The findings indicate that state e-government sites offered 10 information categories and eight social media tools to keep government transparent and citizens engaged. The majority of citizens' comments on the state e-government social media were positive. The state e-government use of social media is still in the introduction stage and has a great growth potential. Therefore, the further research was recommended.
\end{abstract}

Keywords: Democracy, E-government, Social media, Government transparency, Citizen participation.

\section{INTRODUCTION}

Democracy is a form of government by the people, in which all citizens have an equal say in the decisions that affect their lives. Ideally, this includes citizens' equal, direct or indirect participation in the proposal, development, and passage of legislation into law. Democracy can also encompass social, economic, and cultural conditions that enable the free and equal practice of political self-determination through a system of representation usually involving periodically held free elections [e.g., 14, 25].

With the advancement of Internet and World Wide Web technologies, social media, such as Facebook, Twitter, and YouTube, have empowered the grassroots people to engage in democracy campaigns around the globe. For example, the U.S. Tea Party uses YouTube, Facebook, and Twitter on its Web site (www.theteaparty.net) to mobilize a grassroots movement of millions of like-minded Americans from all backgrounds and political parties for "limited federal government, individual freedoms, personal responsibility, free markets, and returning political power to the states and the people" [22].

For the 2011 Singapore General Election in May 2011, a large number of young Singaporeans were first-time voters and more open to political change. With so many young voters, a large part of the campaigning was carried out on the Internet with Facebook, Twitter, and YouTube. The shift from the controlled state media to the free social media propelled the youngest, 24-year-old candidate Miss. Seah to fame. Her Facebook fan site surpassed that of senior statesman Lee Kua Yew, who is widely regarded as the architect of modern Singapore [13].

In the nations where mass media are censored, young people have bypassed the censored media with social media. In Tunisia and Egypt, for instance, citizens mobilized the nation-wide democracy movements in just a few days through the use of Facebook, Twitter, YouTube, and Flickr on their computers and smart phones. By using such tools, Tunisians and Egyptians sent out vital information about where demonstrations were taking place and the second-by-second footages from those in the middle of the protests [e.g., 1, 21]. Very quickly, Tunisians and Egyptians overthrew their corrupted totalitarian governments, respectively.

While the totalitarian governments view the Internet-based social media as big threats to their regimes and try to censor them, the democratic governments consider them as opportunities for better engaging their people in 


\section{Issues in Information Systems}

Volume 13, Issue 1, pp. 247-257, 2012

government affairs. Governments in the Western world use the social media to consult with ordinary citizens and to give them a voice in the democratic process [11]. For instance, on January 21, 2009, the U.S. President Barack Obama issued a memorandum calling for the establishment of a system to promote the government commitments to transparency, public participation, and collaboration. To engage the public, the U.S. Federal agencies are increasingly using Internet-based technologies, such as blogs, wikis, and social networks, as a means for presenting solicitations for public comment and for conducting virtual public meetings [20].

Inspired by the Arab Spring 2011 democracy campaigns, grassroots people in the U.S. mobilized on September 17, 2011, the Occupy Wall Street (OWS) movement fighting to strengthen democracy. They are protesting social and economic inequality, corporate greed, and the power and influence of lobbyists and corporations, particularly from the financial sector, over government [10]. At the protest's start, the majority of the demonstrators were young people; however, as the protest grew the age of the protesters became more diverse, mostly related to the use of social media networks [e.g., 12, 23]. By October 9, similar demonstrations had spread to 70 major cities and over 600 communities in the U.S. [6, 24].

In response to the OWS movement, elected officials and political candidates expressed their viewpoints via the mass and social media. For example, President Obama said in an October 6 news conference [15], "I think it expresses the frustrations the American people feel, that we had the biggest financial crisis since the Great Depression." Vice President Joe Biden likened the protest to the Tea Party, saying, "What are the people up there on the other end of the political spectrum saying? The same thing: 'Look guys, the bargain is not on the level anymore.' In the minds of the vast majority of the American - the middle class is being screwed." [9]

By contrast, the 2012 Republican presidential candidate Herman Cain argued, "Don't blame Wall Street, don't blame the big banks, if you don't have a job and you're not rich, blame yourself!" [4] However, the 2012 Republican presidential candidate Ron Paul [16] came out to refute Cain by saying, "the system has been biased against the middle class and the poor ... the people losing jobs. It wasn't their fault that we've followed a deeply flawed economic system." [16, 19]

Clearly, the Internet-based social media are valuable tools for government commitment to transparency, citizen participation, and collaboration. However, no national study has been documented in the literature to determine the state governments' use of the Internet-based social media. This research gap suggests a need for an empirical study. This paper describes a study that explored how the 50 U.S. state governments and Washington, D.C. use the Internet-based social media on their e-government sites for promoting democracy. Three research questions guided this study:

1. How do state e-government sites deliver information and social media to citizens?

2. How do state e-government sites facilitate two-way interactive communication with citizens on the egovernment social media?

3. How do citizens participate in communication with their state government officials on the e-government social media?

The purpose of the study is to provide the U.S. state e-government administrators with the findings they need for further improving the use of social media for government transparency and citizen participation.

\section{METHODOLOGY}

The population of this study was the official e-government sites of the 50 U.S. states and Washington, D.C. These 51 sites were all used in the study according to the requirement for sample size [8]. Web content analysis is commonly used in assessing organizations' strategies, deliveries, and interactions to customers, employees, investor, and other stakeholders on their Web sites $[5,7,26,27,28]$. To systematically and objectively record how egovernment sites use social media to promote democracy by online interactive communication between government and people, we developed an instrument based on the review of related literature and social networking sites. 


\section{Issues in Information Systems}

Volume 13, Issue 1, pp. 247-257, 2012

Social media are the tools for social interaction, communication, and collaboration over the Internet without time and space limit. These tools include blog (www.blogger.com), online chat (e.g., Instant Messenger, www.downloadmessenger.me; Internet Relay Chat, www.irchelp.org; Talkers, www.talkers.com), Facebook (www.facebook.com), Flickr (www.flickr.com), LinkedIn (www.linkedin.com), MySpace (www.myspace.com), Twitter (www.twitter.com), YouTube (www.youtube.com), and Vimeo (www.vimeo.com). Users can use these social media sites on any Internet-connected computers, smart phones, and mobile devices.

To determine the availability of social media on e-government sites, we included all the foregoing media in the instrument and also added email, Web-based suggestion box, and mobile Web service, which enables users to access the e-government sites from mobile digital devices such as smart phone, iPod Touch, or tablet. Therefore, the instrument consisted of three groups of measurements: (a) e-government information and social media for citizens, (b) interactive communication on e-government social media, and (c) citizens' participation on e-government social media.

One hundred and two business students at a Midwestern state university participated in this study as an experiential exercise when learning Internet technologies. The students were trained to use the instrument and also understood that their participation in the study would be anonymous and not have an impact on their course grade, which was required by the university Institutional Review Board protocol. The 102 participating students were randomly formed in pairs, with each pair of two students assigned to one of the 51 sites for the exercise in a computer lab connected with the Internet. Each pair of students seated next to each other and collected data from the assigned site independently. When completing the data collection, they compared their collected data and reached agreement if there was any difference between them. When students encountered any difficulty and could not come to a team solution or agreement, they met with the researchers for problem solving and assurance of data quality. The collected data were coded and entered into Excel spreadsheet table for statistical analysis.

\section{FINDINGS}

Research Question 1 asked, "How do state e-government sites deliver information and social media to citizens?" The U.S. state e-government sites delivered information and social media to their citizens and visitors in three ways: languages, information categories, and interactive social media.

First, to enable as many citizens as possible to participate in state government affairs, the state e-government sites were available not only in English language but also in some other languages that the minority citizens in those states speak daily at home or in their ethnic communities. As Figure 1 shows, Spanish was the most popular second language available on 18 state e-government sites, followed by French on 10 state e-government sites, German on 8 state sites, Chinese on 8 state sites, Korean on 7 state sites, Japanese on 6 state sites, and Italian on 5 state sites. Norwegian and Finnish languages were least popular and only available on one state e-government site, respectively.

Second, to keep government transparent and citizens well informed, 10 main categories of state government information were presented on the state e-government sites. As Figure 2 illustrates, these 10 information categories had respective navigation buttons and links and were usually named as follows: Government Agency Sites $(n=51$, $100 \%)$, Search Tools (50, 98\%), Online Services ( $n=50$, 98\%), Business/Trade/Laws $(n=48$, 94\%), Press Release/Updates $(n=45,88 \%)$, Nation and State Facts $(n=44,86 \%)$, Issues and Events $(n=35,69 \%)$, Frequently Asked Questions $(n=27,53 \%)$, and Site Map $(n=21,41 \%)$.

Third, to promote citizen participation and collaboration in government decision-making processes, the egovernment sites also offered some social media tools for citizens' online interaction, communication, networking, and collaboration. As Figure 2 shows, these social media tools were Contact Us Email $(n=51,100 \%)$, Twitter $(n=30$, $59 \%)$, Facebook $(n=26,51 \%)$, Suggestion Box $(n=25,49 \%)$, Chat $(n=24,47 \%)$, Flickr $(n=23,45 \%)$, YouTube $(n=20,39 \%)$, Mobile Web Service $(n=16,31 \%), \operatorname{Blog}(n=7,14 \%)$, LinkedIn $(n=3,6 \%)$, and Vimeo $(n=3,6 \%)$. 


\section{Issues in Information Systems}

Volume 13., Issue No., pp. No., 2012

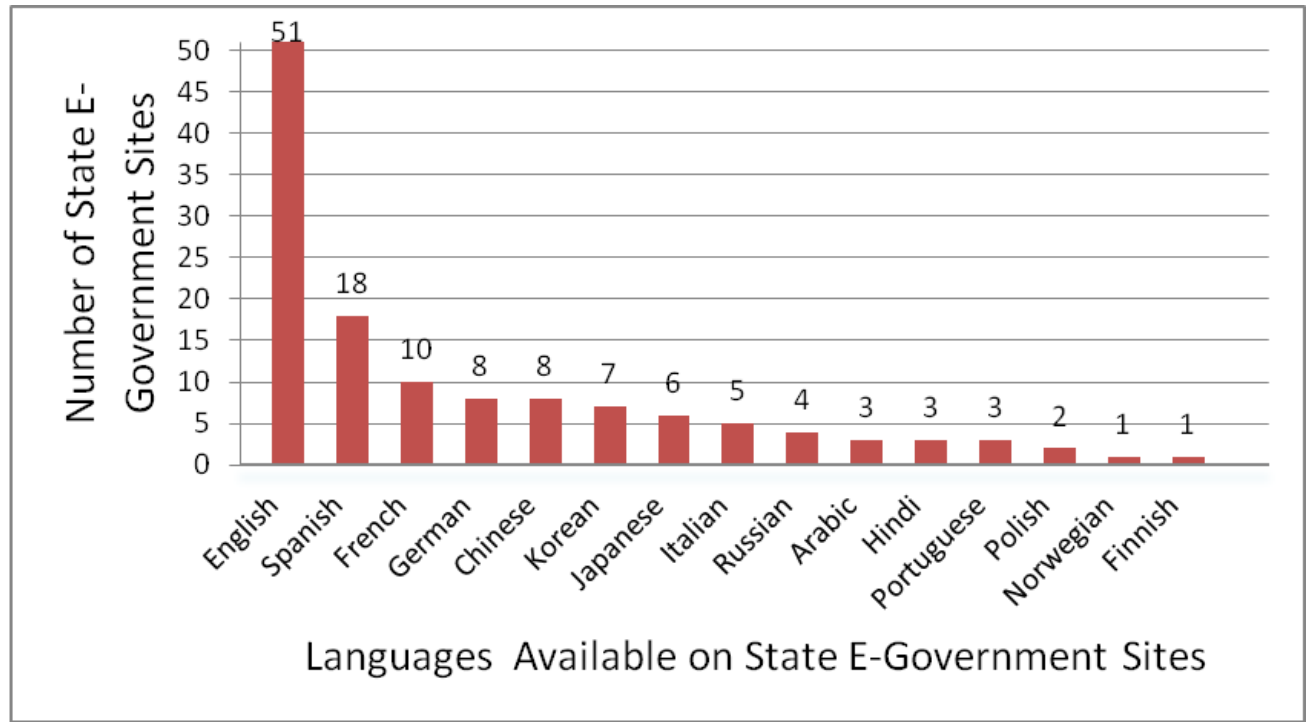

Figure 1. Languages Available on the U.S. State E-Government Sites

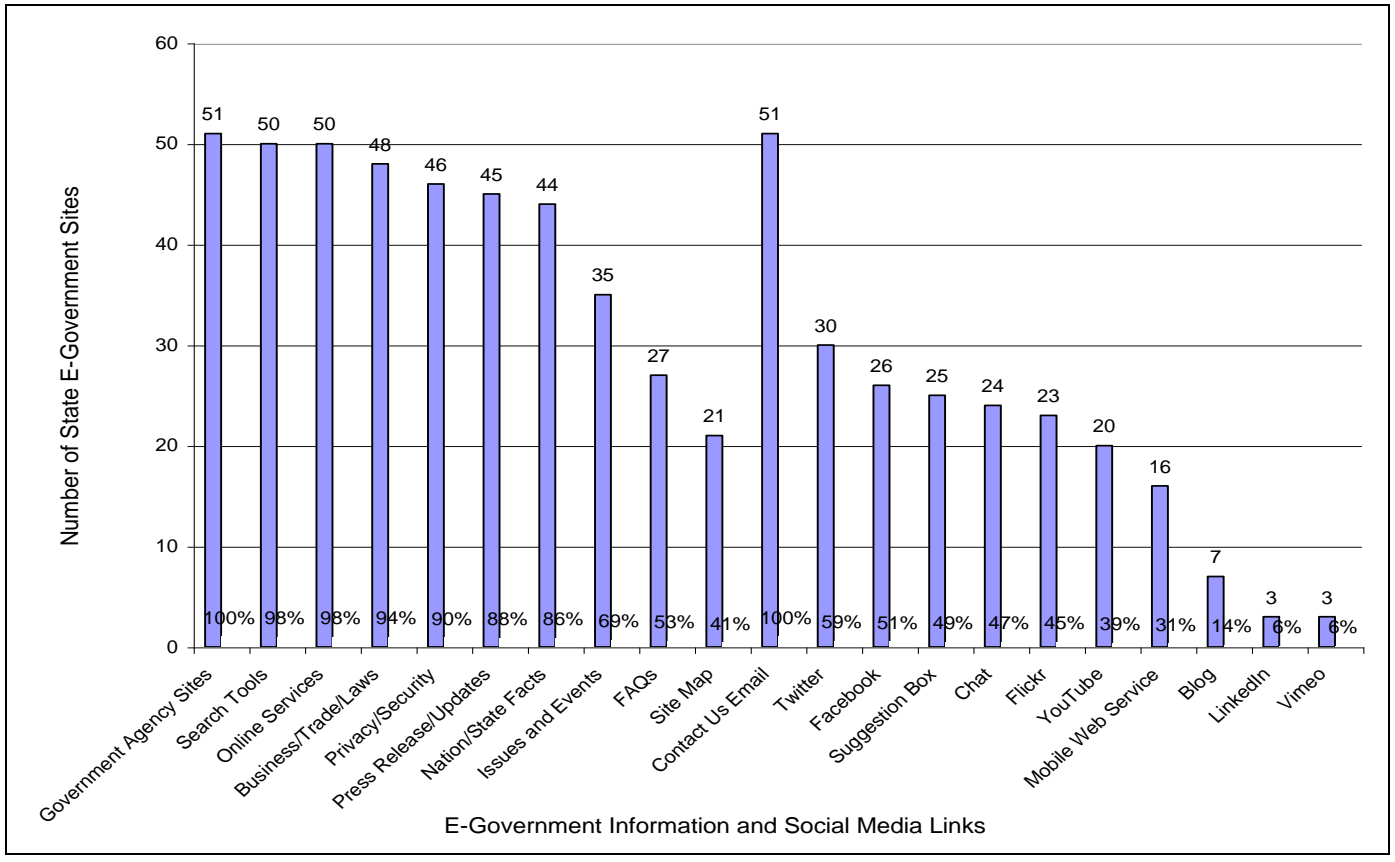

Figure 2. Information and Social Media Links on State E-Government Sites 


\section{Issues in Information Systems}

Volume 13., Issue No., pp. No., 2012

Research Question 2 asked, "How do state e-government sites facilitate two-way interactive communication with citizens on the e-government social media?" Table 1 indicates the state government officials' use of various social media to communicate interactively with citizens and facilitate government transparency and citizen participation. Twitter was available on 30 state e-government sites and it was used mainly to post government announcements and comments of state events (87\%; e.g., "Announcement of pay raises and pay-for-performance system for DC teachers" and seminar on "Creating and Maintaining your Biz Plan"), current issues (80\%; e.g., "Refunds Available for Health Insurance Scam Victims" and "Citizens continue voting for Milford to win the "This Place Matters Community Challenge."), important decisions (63\%; e.g., "Governor Ritter Appoints Three New Judges" and “

Governor Perdue Announces Extension of Grants for Spouses of Fort Benning Soldiers"), and new initiatives (40\%; e.g., "New to Colorado.gov - Look through Colorado's Cold Cases: www.colorado.gov/coldcase" and "To Reduce Repeat Offenses, Governor Markell Releases Re-entry Plan").

Facebook was available on 26 state e-government sites. The majority of the postings were government announcements, updates, and comments (96\%; e.g., "Department of the Treasury - Colorado Tax Tracks is now available!" "Congratulations to the Delaware Symphony Orchestra for their Latin Grammy nomination!" and "New Stimulus Accountability website launched") and new initiatives (58\%; e.g., "Department of Homeland Security launched the "see something, say something" suspicious package awareness campaign in DC"). In the meantime, nearly half of the postings on state e-government Facebook were state current issues (46\%; e.g., "District Government is already taking action to slash its emissions of greenhouse gases responsible for climate change and is on target to reduce emissions $20 \%$ by 2012 and 30\% by 2020") and important decisions (42\%; e.g., DC Public Schools announces implementation of pay raises and pay-for-performance system for teachers" and "Signing of a bill that allows teens getting their driver's license at the DMV to pre-register to vote").

Flickr was available on 23 state e-government sites, and all of these sites used Flickr to display photos of state sceneries, buildings, parks, historical attractions, etc. In addition, a few sites also present photos of the current issues of the states (17\%; e.g., "Early education and safe walking routes for students") and new initiatives (9\%; e.g., "Reintroduction of the streetcar into D.C. after two generations").

YouTube was used by 20 state e-government sites. The majority of the videos posted on YouTube were advertisements and promotions of the states $(85 \%$; e.g., video that gives "a broad overview of how DC utilizes technology") and current issues of the states (65\%; e.g., "Governor talking about bringing jobs to the state" and "Canon City Bill Signing").

While Twitter, Facebook, Flickr, and YouTube were the popular social media on state e-government sites, Blog and Vimeo were used by a small minority of the state e-government sites for sharing important decisions, current issues, and new initiatives of the states.

As by October 21, 2011, the vast majority (90\%) of the state e-government sites had not posted any news or press release nor communication between state elected officials and citizens on the issue of the "Occupy" movement, even though there were "Occupy" protests in front of numerous state capitols and the police forces were present to ensure the protesters obey the laws [e.g., 2, 3, 18].

Research Question 3 asked, "How do citizens participate in communication with their state government officials on the e-government social media?" Table 2 illustrates the number of citizens who visited the state e-government social media and wrote comments there. More than 20 state e-government sites used Twitter, Facebook, and Flickr. Around one third of these sites had 10 or more people at each site wrote comments on these three social media. About another one third to nearly half of the sites had one to nine people at each site wrote comments on these social media. In contrast, approximately the last one third of the sites had no citizens or visitors left comments on these social media. 


\section{Issues in Information Systems}

Volume 13., Issue No., pp. No., 2012

TABLE 1

Types of Information Posted on the E-Government Social Media

\begin{tabular}{|c|c|c|c|c|}
\hline $\begin{array}{l}\text { Social } \\
\text { Media } \\
\end{array}$ & Types of Information & $\begin{array}{c}\text { \# of Sites } \\
\text { Offering } \\
\text { Such } \\
\text { Media }\end{array}$ & Frequency & Percentage \\
\hline \multirow[t]{5}{*}{ Twitter } & & 30 & & \\
\hline & Announcements/comments of state events & & 26 & $87 \%$ \\
\hline & Current issues & & 24 & $80 \%$ \\
\hline & Important decisions & & 19 & $63 \%$ \\
\hline & New initiatives & & 12 & $40 \%$ \\
\hline \multirow[t]{5}{*}{ Facebook } & & 26 & & \\
\hline & Announcements/updates/comments & & 25 & $96 \%$ \\
\hline & New initiatives & & 15 & $58 \%$ \\
\hline & Current issues & & 12 & $46 \%$ \\
\hline & Important decisions & & 11 & $42 \%$ \\
\hline \multirow[t]{5}{*}{ Flickr } & & 23 & & \\
\hline & Photos of state sceneries, buildings... & & 23 & $100 \%$ \\
\hline & Current issues & & 4 & $17 \%$ \\
\hline & New initiatives & & 2 & $9 \%$ \\
\hline & Other & & 22 & $96 \%$ \\
\hline \multirow[t]{5}{*}{ YouTube } & & 20 & & \\
\hline & State advertisement/promotion & & 17 & $85 \%$ \\
\hline & Current issues & & 13 & $65 \%$ \\
\hline & New initiatives & & 7 & $35 \%$ \\
\hline & Important decisions & & 4 & $20 \%$ \\
\hline \multirow[t]{4}{*}{ Blog } & & 7 & & \\
\hline & Important decisions & & 6 & $86 \%$ \\
\hline & Current issues & & 5 & $71 \%$ \\
\hline & New initiatives & & 2 & $29 \%$ \\
\hline \multirow[t]{5}{*}{ Vimeo } & & 3 & & \\
\hline & Important decisions & & 2 & $67 \%$ \\
\hline & New initiatives & & 2 & $67 \%$ \\
\hline & Presentations & & 2 & $67 \%$ \\
\hline & Current issues & & 1 & $33 \%$ \\
\hline
\end{tabular}

A total of 20 state e-government sites used YouTube to share videos with citizens and visitors. Of these 20 sites, only three sites had some people viewed those videos and wrote comments there whereas the other 17 sites received no comments from viewers. 


\section{Issues in Information Systems}

Volume 13., Issue No., pp. No., 2012

Similarly, only three state e-government sites used Vimeo to share videos with citizens and visitors but received no comments from viewers at all. However, only seven state e-government sites had Blogs, but all of them received comments from the readers. The majority ( $71 \%)$ of them had 10 or more people, respectively, read the blog postings and left comments there.

As Table 3 presents, while the majority of the comments written on the state e-government social media were positive, a minority of them were neutral, and another small minority were negative. For instance, Indiana Governor Mitch Daniels posted his video remarks at Butler Basketball campus-wide celebration on YouTube and received the following positive comment: "Thank you Mitch for those comforting words.... I have been hurting for Butle, but your words are a tremendous salve to many a Hoosier's heart." An example of negative comment was posted by Mr. Tom Sherwood, Reporter of NBC4 Washington, D.C. on the Twitter page of Mr. Vincent Gary, Mayor of D.C. that "Gary announces public hearings on budget he's already submitted to council. Cart before horse?" In response, Gary twitted, "The Budget Town Halls are not "public hearings" but education-and-feedback sessions."

\section{SUMMARY AND CONCLUSIONS}

The 51 e-government sites were presented not only in English but also in some other languages based on the state demographic needs. Spanish was the most popular second language, followed by French, German, Chinese, Korean, Japanese, Italian, Russian, Arabic, Hindi, Portuguese, Polish, Norwegian, and Finnish languages. This approach appears to enable as many citizens as possible to participate in government affairs.

To keep government transparent and citizens informed, the following 10 main information categories were presented on the state e-government sites:

- Government Agency Sites ( $n=51,100 \%)$

- Search Tools $(n=50,98 \%)$

- Online Services $(n=50,98 \%)$

- Business/Trade/Laws $(n=48,94 \%)$

- Press Release/Updates $(n=45,88 \%)$

- Nation and State Facts $(n=44,86 \%)$

- Issues and Events $(n=35,69 \%)$

- FAQs $(n=27,53 \%)$

- $\quad$ Site $\operatorname{Map}(n=21,41 \%)$

Clearly, the state e-government sites that failed to post Site Map, Frequently Asked Questions, Issues and Events ... need an improvement over those missing pages, which are important for citizens' participation in government affairs.

To promote citizen participation, the e-government sites also chose to offer the following eight popular social media tools for citizens' online interaction, communication, networking, and collaboration:

- $\quad$ Contact Us Email $(n=51,100 \%)$

- Twitter $(n=30,59 \%)$

- Facebook $(n=26,51 \%)$

- Suggestion Box $(n=25,49 \%)$

- $\quad$ Chat $(n=24,47 \%)$

- $\operatorname{Flickr}(n=23,45 \%)$

- YouTube $(n=20,39 \%)$

- Mobile Web Service $(n=16,31 \%)$ 


\section{Issues in Information Systems}

Volume 13., Issue No., pp. No., 2012

TABLE 2

Citizens' Participation in Using Social Media on State E-Government Sites

\begin{tabular}{|c|c|c|c|c|}
\hline $\begin{array}{l}\text { Social } \\
\text { Media } \\
\end{array}$ & Participation & & $\begin{array}{c}\text { \# of Sites } \\
\text { Offering } \\
\text { Such } \\
\text { Media } \\
\end{array}$ & Percentage \\
\hline \multirow[t]{5}{*}{ Twitter } & 10 or more people participated with comments & & 8 & $27 \%$ \\
\hline & 5-9 people participated with comments & & 7 & $23 \%$ \\
\hline & 1-4 people participated with comments & & 5 & $17 \%$ \\
\hline & 0 person participated with comments & & 10 & $33 \%$ \\
\hline & & Total & 30 & $100 \%$ \\
\hline \multirow[t]{5}{*}{ Facebook } & 10 or more people participated with comments & & 9 & $35 \%$ \\
\hline & 5-9 people participated with comments & & 6 & $23 \%$ \\
\hline & 1-4 people participated with comments & & 6 & $23 \%$ \\
\hline & 0 person participated with comments & & 5 & $19 \%$ \\
\hline & & Total & 26 & $100 \%$ \\
\hline \multirow[t]{5}{*}{ Flickr } & 10 or more people participated with comments & & 7 & $30 \%$ \\
\hline & 5-9 people participated with comments & & 2 & $9 \%$ \\
\hline & 1-4 people participated with comments & & 4 & $17 \%$ \\
\hline & 0 person participated with comments & & 10 & $43 \%$ \\
\hline & & Total & 23 & $100 \%$ \\
\hline \multirow[t]{5}{*}{ YouTube } & 10 or more people participated with comments & & 0 & $0 \%$ \\
\hline & 5-9 people participated with comments & & 1 & $5 \%$ \\
\hline & 1-4 people participated with comments & & 2 & $10 \%$ \\
\hline & 0 person participated with comments & & 17 & $85 \%$ \\
\hline & & Total & 20 & $100 \%$ \\
\hline \multirow[t]{5}{*}{ Blog } & 10 or more people participated with comments & & 5 & $71 \%$ \\
\hline & 5-9 people participated with comments & & 0 & $0 \%$ \\
\hline & 1-4 people participated with comments & & 2 & $29 \%$ \\
\hline & 0 person participated with comments & & 0 & $0 \%$ \\
\hline & & Total & 7 & $100 \%$ \\
\hline
\end{tabular}




\section{Issues in Information Systems}

Volume 13., Issue No., pp. No., 2012

TABLE 3

Citizens' Comments of Government Officials' Communication on Social Media

\begin{tabular}{|c|c|c|c|c|}
\hline Social Media & Citizens' Comments & & Frequency & Percentage \\
\hline \multirow[t]{4}{*}{ Facebook } & Positive & & 180 & $46 \%$ \\
\hline & Neutral & & 100 & $26 \%$ \\
\hline & Negative & & 111 & $28 \%$ \\
\hline & & Total & 391 & $100 \%$ \\
\hline \multirow[t]{4}{*}{ Twitter } & Positive & & 256 & $77 \%$ \\
\hline & Neutral & & 37 & $11 \%$ \\
\hline & Negative & & 40 & $12 \%$ \\
\hline & & Total & 333 & $100 \%$ \\
\hline \multirow[t]{4}{*}{ Flickr } & Positive & & 125 & $81 \%$ \\
\hline & Neutral & & 22 & $14 \%$ \\
\hline & Negative & & 8 & $5 \%$ \\
\hline & & Total & 155 & $100 \%$ \\
\hline \multirow[t]{4}{*}{ Blog } & Positive & & 49 & $60 \%$ \\
\hline & Neutral & & 16 & $20 \%$ \\
\hline & Negative & & 16 & $20 \%$ \\
\hline & & Total & 81 & $100 \%$ \\
\hline \multirow[t]{4}{*}{ YouTube } & Positive & & 16 & $67 \%$ \\
\hline & Neutral & & 7 & $29 \%$ \\
\hline & Negative & & 1 & $4 \%$ \\
\hline & & Total & 24 & $100 \%$ \\
\hline
\end{tabular}

Obviously, except for Contact Us Email, around half of the state e-government sites did not offer the popular social media such as Twitter, Facebook, and YouTube. Since these social media tools play an important role in promoting democracy [e.g., 1, 21], the state e-government administrators need to consider offering these tools on their sites.

While Twitter and Facebook were used mainly to post (a) announcements and comments of state events, (b) current issues, (c) important decisions, and (d) new initiatives, YouTube and Flickr were primarily used to display video clips and photos for promoting states and communicating current issues. Citizens wrote comments on the majority of the state e-government Twitter, Facebook, and Flicker pages. However, approximately one third of the state egovernment Twitter, Facebook, and Flicker pages showed zero comment from citizens. In addition, of 20 state egovernment sites using YouTube, only three sites showed that citizens wrote comments after viewing the video clips on their YouTube pages.

Moreover, the review of citizens' comments identified three types of comments: positive, neutral, and negative. The majority of the comments written on the state e-government social media were positive, a minority of them was neutral, and another small minority was negative. These three types of comments provide state government officials with valuable feedback and input from the grassroots people, such as (a) how engaging and motivational the government communication was to citizens, (b) how citizens view government initiatives and handling of state 


\section{Issues in Information Systems}

Volume 13., Issue No., pp. No., 2012

affairs, and (c) how actively the citizens have participated online in government decision-making processes. When state government officials genuinely make good use of citizens' comments, more citizens will use the e-government social media as a means for their participation, comments, and collaboration. As a result, the states will be more democratic, united, and prosperous politically and economically.

\section{RECOMMENDATIONS FOR FURTHER STUDY}

This study identified that the U.S. state e-government use of the Internet-based social media for promoting democracy is in the introduction state and has great growth potential. A follow-up study is recommended to be undertaken in three years to assess (a) how maturely the state e-government sites will use the social media for soliciting citizens' participation, comments, and collaboration and (b) how actively citizens will participate in state government affairs on the e-government sites.

In addition, similar research is recommended to study how governments in other nations use the social media to promote democracy. The findings of this comparative study will be beneficial for government officials and citizens of the participating nations to learn the better ways of using social media for promoting democracy.

\section{REFERENCES}

1. Arnstine, M. (2011, February 16). Social media: More useful than we think. Retrieved from http://www.diamondbackonline.com/opinion/social-media-more-useful-than-we-think-1.1997599

2. Associate Press. (2011, October 21). "Occupy" protesters gather next to N.Y. State Capitol. MyFoxdc.com. Retrieved from http://www.myfoxdc .com/dpps/news/protesters-gather-next-to-ny-state-capitol-dpgapx20111021-to_15588398

3. Bellamy, J. (2011, October 14). Occupy Columbia, S.C. to protest at State House Saturday. Wltx.com. Retrieved from http://www.wltx .com/news/national/article/155305/2/Occupy-Columbia-to-Protest-at-State-HouseSaturday

4. Bingham, A. (2011, October 5). Herman Cain tells Occupy Wall Street protesters to "blame yourself." ABC NEWS. Retrieved from http://abcnews.go.com/Politics/cain-tells-occupy-wall-street-protestersblame/story?id=14674829

5. Boggs, R. A., \& Walters, D. (2006). A longitudinal look at e-government in practice. Issues in Information Systems, 7(2), 161-164.

6. Brohinsky, S. (2011, October 11). As economic frustrations grow, protesters gain support: Majority of American have a favorable opinion of the occupy movement. Time/ABT SRBI. Retrieved from http://www.srbi.com/ Economics_2011_Poll.html\#

7. Campbell, D. \& Beck, A. C. (2004). Answering Allegations: The Use of the Corporate Website for Restorative Ethical and Social Disclosure. Business Ethics, 13(2), 100.

8. Cochran, W. G. (1977). Sampling techniques ( $3^{\text {rd }}$ ed.). New York: John Wiley and Sons.

9. Daly, C. B. (2011, October 6). Biden: The "middle class has been screwed." CBS NEWS. Retrieved from http://www.cbsnews.com/8301-503544_162-20116717-503544.html

10. Dobnik, W. (2011, October 2). Wall Street protesters: We're in for the long haul. Business Week. Retrieved from http://www.businessweek.com/ap/financialnews/D9Q4CNR81.htm

11. Evans, T. (2010). Social networking sites have transformed the political landscape. Retrieved from http://networkconference.netstudies.org/2010/04/social-networking-sites-have-transformed-the-politicallandscape/

12. Kleinfield, N. R. \& Buckley, C. (2011, September 30). Wall Street occupiers, protesting till whenever. New York Times. Retrieved from http://www. nytimes.com/2011/10/01/nyregion/wall-street-occupiers-protesting-tillwhenever.html?_r=3\&ref=occupywallstreet

13. Leyl, S. (2011). Singapore election: Young voters could be the key. BBC News. Retrieved from http://www.bbc.co.uk/news/business-13305828 


\section{Issues in Information Systems}

Volume 13., Issue No., pp. No., 2012

14. Merriam-Webster. (2011). Definition of democracy. Retrieved from http://www.merriam-webster.com/ dictionary/democracy?show $=0 \& \mathrm{t}=1303397738$

15. Office of the Press Secretary. (2011, October 6). News conference by the president. The White House. Retrieved from http://www.whitehouse.gov/the-press-office/2011/10/06/news-conference-president

16. Paul, R. (2011, October 6). Economy biased against the poor. Situation Room with Wolf Blitzer. CNN. October 6, 2011. Retrieved from http://edition.cnn. com/video/?/video/politics/2011/10/06/tsr-paul-occupy-protests.cnn

17. Rushkoff, D. (2011, October 5). Think Occupy Wall Street is a phase? You don't get it. CNN. Retrieved from http://edition.cnn.com/2011/10/05/opinion/rushkoff-occupy-wall-street/

18. Seward, C. (2011, October 16). Occupy Atlanta occupies steps of state capitol. The Atlanta Journal Constitution. Retrieved from http://www.ajc.com/ news/atlanta/occupy-atlanta-occupies-steps-1201395.html

19. Sink, J. (2011, October 3). Paul supports anti-Wall Street protests. The Hill's Blog Briefing Room. Retrieved from http://thehill.com/blogs/blog-briefing-room/news/185081-paul-offers-support-for-anti-fed-occupy-wallstreet-protestors

20. Sunstein, C. R. (2010, April 7). The Social Media, Web-based Interactive Technologies, and the Paperwork reduction Act. Executive Office of the President of U.S.A. Retrieved from http://www.whitehouse.gov/sites/default/files/omb/assets/inforeg/SocialMediaGuidance_04072010.pdf

21. Tavoularis, A. (2011, February 14). Social media paving the way for grassroots revolutions. Retrieved from http://www.theticker.org/mobile/about/2.8217/social-media-paving-the-way-for-grassroots-revolutions1.2467821

22. Tea Party. (2011, April 1). What is the Tea Party? The Tea Paty.net. Retrieved from http://www.theteaparty.net/

23. Vitchers, T. E. (2011, September 26). Occupying - not rioting -Wall Street. Huffington Post. Retrieved from http://www.huffingtonpost.com/tracey-e-vitchers/occupyingnot-riotingwall-_b_980003.html

24. Walters, J. (2011, October 8). Occupy America: Protests against Wall Street and inequality hit 70 cities. The Guardian. Retrieved from http://www.guardian.co.uk/world/2011/oct/08/occupy-america-protests-financialcrisis

25. Wikipedia. (2011). Definition of democracy. Retrieved from http://en.wikipedia.org/wiki/Democracy

26. Wilkinson, V. O. \& Cappel, J. J. (2005). Impact of economic prosperity and population on e-government involvement. Issues in Information Systems, (6), 204-209.

27. Zhao, J. J. \& Zhao, S. Y. (2004). Internet Technologies Used by INC. 500 Corporate Web Sites, Issues in Information Systems, (4), 366-372.

28. Zhao, J. J., Truell, A. D., \& Alexander, M. W. (2006). User-interface design characteristics of Fortune 500 B2C e-commerce sites and industry differences. The Delta Pi Epsilon Journal, 48(1), 43-55. 